\title{
Ocena zgodności z Konstytucją nowelizacji ustawy o Krajowym Rejestrze Sądowym w zakresie zniesienia obowiązku doręczenia postanowień o wpisie do rejestru dłużników niewypłacalnych ${ }^{1}$
}

\begin{abstract}
Evaluation of conformity to the Constitution of the amendment of the National Court Register Act, as regards the abolition of the obligation to deliver decisions about the registration in the insolvent debtors register: The subject of questions of law submitted to the Constitutional Tribunal is the provision of the amendment of the National Court Register Act, which discharged the courts, that have been issuing orders about the registration in insolvent debtors register, from the obligation to deliver them and which also determined, that those orders are not subject to appeal. In the draft Sejm's position it was concluded, that the provision introduced by the amendment does not conform to the Constitution. Such conclusion is formed after determining that, the provision in questions causes an effect that individuals may be registered in the insolvent debtors register without their knowledge and without any opportunity to present counterarguments during court proceedings.
\end{abstract}

Keywords: National Court Register, civil procedure, Constitutional Tribunal

Słowa kluczowe: Krajowy Rejestr Sądowy, postępowanie cywilne, Trybunał Konstytucyjny

Doktor hab. nauk prawnych, adiunkt Wydziału Prawa i Administracji Uniwersytetu Mikołaja Kopernika w Toruniu, ekspert ds. legislacji BAS - karol.dobrzeniecki@umk.pl • https://orcid.org/0000-0002-6364-9793

1 Projekt stanowiska w sprawie pytań prawnych - trzech postanowień Sądu Rejonowego w Białymstoku z dnia 2 lipca 2018 r. (sygnatury akt: BI. XII Ns-Rej. KRS 4134/18/977, BI. XII Ns-Rej. KRS 3194/18/832, BI. XII Ns-Rej. KRS 4265/18/442). Przedmiotem kontroli jest art. 49 ustawy z dnia 26 stycznia 2018 r. o zmianie ustawy o Krajowym Rejestrze Sądowym oraz niektórych innych ustaw (Dz. U. poz. 398, ze zm.) w zakresie dotyczącym art. 55 ustawy z dnia 20 sierpnia 1997 r. o Krajowym Rejestrze Sądowym (t.j. Dz. U. z 2018 r., poz. 986, ze zm.); sygn. akt P 9/18 (BAS-WAKU-2376/18) sporządzony 15 lutego 2019 r., sygn. akt P 9/18; BAS-WAKU 2376/18. 
Na podstawie art. 69 ust. 2 w związku z art. 42 pkt 3 ustawy z dnia 30 listopada 2016 r. o organizacji i trybie postępowania przed Trybunałem Konstytucyjnym (Dz. U. poz. 2072), w imieniu Sejmu Rzeczypospolitej Polskiej przedkładam wyjaśnienia w sprawie połączonych do wspólnego rozpoznania pod sygnaturą P 9/18 pytań prawnych Sądu Rejonowego w Białymstoku, jednocześnie wnosząc o stwierdzenie, że art. 49 ustawy z dnia 26 stycznia 2018 r. o zmianie ustawy o Krajowym Rejestrze Sądowym oraz niektórych innych ustaw (Dz. U. poz. 398, ze zm.) w zakresie dotyczącym art. 55 pkt 4 i 5 ustawy z dnia 20 sierpnia 1997 r. o Krajowym Rejestrze Sądowym (t.j. Dz. U. z 2018 r., poz. 986, ze zm.), jest niezgodny z art. 45 ust. 1 Konstytucji.

Sejm wnosi także o umorzenie postępowania w pozostałym zakresie na podstawie art. 59 ust. 1 pkt 2 ustawy o organizacji i trybie postępowania przed Trybunałem Konstytucyjnym, ze względu na niedopuszczalność wydania wyroku.

\section{Uzasadnienie}

\section{Przedmiot kontroli}

1. W dniu 1 października 2018 r. do Kancelarii Sejmu wpłynęło zawiadomienie Prezesa Trybunału Konstytucyjnego o wszczęciu postępowania przed Trybunałem Konstytucyjnym (dalej: TK, Trybunał) w sprawie pytań prawnych - trzech postanowień Sądu Rejonowego w Białymstoku (dalej: sąd pytający; SR) z dnia 2 lipca 2018 r. (sygnatury akt: BI. XII Ns-Rej. KRS 4134/18/977, BI. XII Ns-Rej. KRS 3194/18/832, BI. XII Ns-Rej. KRS 4265/18/442) łącznie rozpoznawanych pod wspólną sygnaturą P 9/18 z uwagi na tożsamość przedmiotu sprawy. Przedmiotem kontroli jest art. 49 ustawy z dnia 26 stycznia 2018 r. o zmianie ustawy o Krajowym Rejestrze Sądowym oraz niektórych innych ustaw (Dz. U. poz. 398, ze zm.; dalej: ustawa nowelizująca) w zakresie dotyczącym art. 55 ustawy z dnia 20 sierpnia 1997 r. o Krajowym Rejestrze Sądowym (t.j. Dz. U. z 2018 r., poz. 986, ze zm.; dalej: ustawa o KRS).

Kwestionowany artykuł ustawy nowelizującej stanowi:

„Art. 49. W sprawach wszczętych od dnia wejścia w życie niniejszej ustawy postanowienia w przedmiocie wpisów, o których mowa w art. 41 pkt 5 i art. 55 ustawy zmienianej w art. 1, nie wymagają doręczenia i nie podlegają zaskarżeniu".

2. Artykuł 49 zawiera odesłania. W zakresie objętym przedmiotem pytań prawnych rozpatrywanych $\mathrm{w}$ niniejszym postępowaniu znajduje się odesłanie do art. 55 ustawy o KRS.

„Art. 55. Do rejestru dłużników niewypłacalnych wpisuje się z urzędu:

1) osoby fizyczne wykonujące działalność gospodarczą, jeżeli ogłoszono ich upadłość lub jeżeli wniosek o ogłoszenie ich upadłości został prawomocnie oddalony na podstawie art. 13 ustawy z dnia 28 lutego 2003 r. - Prawo upadłościowe albo umorzono prowadzoną przeciwko nim egzekucję sądową lub admini- 
stracyjną z uwagi na fakt, iż z egzekucji nie uzyska się sumy wyższej od kosztów egzekucyjnych;

1a) osoby fizyczne nieprowadzące działalności gospodarczej, jeżeli ogłoszono ich upadłość;

2) wspólników ponoszących odpowiedzialność całym swoim majątkiem za zobowiązania spółki, z wyłączeniem komandytariuszy w spółce komandytowej, jeżeli ogłoszono jej upadłość lub jeżeli wniosek o ogłoszenie jej upadłości został prawomocnie oddalony na podstawie art. 13 ustawy z dnia 28 lutego 2003 r. Prawo upadłościowe albo umorzono prowadzoną przeciwko nim egzekucję sądową lub administracyjną z uwagi na fakt, iż z egzekucji nie uzyska się sumy wyższej od kosztów egzekucyjnych;

3) dłużników, którzy zostali zobowiązani do wyjawienia majątku w trybie przepisów Kodeksu postępowania cywilnego o postępowaniu egzekucyjnym;

4) osoby, które przez sąd upadłościowy zostały pozbawione prawa prowadzenia działalności gospodarczej na własny rachunek oraz pełnienia funkcji członka rady nadzorczej, reprezentanta lub pełnomocnika w spółce handlowej, przedsiębiorstwie państwowym, spółdzielni, fundacji lub stowarzyszeniu;

5) dłużników, o których mowa w art. $1086 \$ 4$ Kodeksu postępowania cywilnego".

Artykuł 13 ustawy z 28 lutego 2003 r. - Prawo upadłościowe (t.j. 2017, poz. 2344, ze zm.; dalej: u.p.u.) ma następujące brzmienie.

„Art. 13. 1. Sąd oddali wniosek o ogłoszenie upadłości, jeżeli majątek niewypłacalnego dłużnika nie wystarcza na zaspokojenie kosztów postępowania lub wystarcza jedynie na zaspokojenie tych kosztów.

2. Sąd może oddalić wniosek o ogłoszenie upadłości w razie stwierdzenia, że majątek dłużnika jest obciążony hipoteką, zastawem, zastawem rejestrowym, zastawem skarbowym lub hipoteką morską w takim stopniu, że pozostały jego majątek nie wystarcza na zaspokojenie kosztów postępowania.

2a. Oddalając wniosek o ogłoszenie upadłości, sąd ustala, czy materiał zgromadzony w sprawie daje podstawę do rozwiązania podmiotu wpisanego do Krajowego Rejestru Sądowego bez przeprowadzania postępowania likwidacyjnego.

3. Jeżeli zostanie uprawdopodobnione, że obciążenia majątku dłużnika są bezskuteczne według przepisów ustawy albo gdy dokonane zostały w celu pokrzywdzenia wierzycieli, jak również jeżeli zostanie uprawdopodobnione, że dłużnik dokonał innych czynności prawnych bezskutecznych według przepisów ustawy, którymi wyzbył się majątku wystarczającego na zaspokojenie kosztów postępowania, a okoliczności sprawy wskazują, że zastosowanie przepisów o bezskuteczności i zaskarżaniu czynności upadłego doprowadzi do uzyskania majątku o wartości przekraczającej przewidywaną wysokość kosztów, przepisów ust. 1 i 2 nie stosuje się.

4. Postanowienie o oddaleniu wniosku o ogłoszenie upadłości na podstawie ust. 1 lub 2 obwieszcza się". 
Artykuł $1086 \$ 4$ k.p.c. ma brzmienie: „W razie powstania zaległości za okres dłuższy niż 6 miesięcy komornik z urzędu składa wniosek do Krajowego Rejestru Sądowego o wpis dłużnika do rejestru dłużników niewypłacalnych. Wniosek komornika nie podlega opłacie sądowej”.

3. Objęty przedmiotem pytań prawnych przepis ustawy nowelizującej zwolnił sądy wydające postanowienia w przedmiocie wpisów, o których mowa w art. 55 ustawy o KRS, z obowiązku ich doręczenia oraz przesądził, iż postanowienia te nie podlegają zaskarżeniu. Zakres zastosowania tego przepisu obejmuje postanowienia wydawane w postępowaniach wszczętych po 14 marca $2018 \mathrm{r}$.

Postępowania rejestrowe, o których mowa w art. 55 ustawy o KRS, są to postępowania nieprocesowe, prowadzone $\mathrm{z}$ urzędu, kończące się wpisem osoby (uczestnika postępowania) do rejestru dłużników niewypłacalnych (dalej: RDN) lub, w przypadku stwierdzenia braku przesłanek uzasadniających taki wpis, umorzeniem postępowania wszczętego z urzędu. Okolicznością, która zazwyczaj powoduje wszczynanie postępowania w przedmiocie wpisu, jest informacja uzyskiwana przez sąd rejestrowy od sądu upadłościowego, sądu egzekucyjnego, od komornika sądowego lub wierzyciela, z którego wniosku ogłoszono upadłość dłużnika, wierzyciela alimentacyjnego, w stosunku do którego dłużnik zalega ze świadczeniem za okres dłuższy niż 6 miesięcy, czy wierzyciela prowadzącego przeciwko dłużnikowi egzekucję, w ramach której miało miejsce sądowe wyjawienie majątku (zob. M. Tarska, Komentarz do art. 55 ustawy o Krajowym Rejestrze Sądowym [w:] Kodeks spółek handlowych. Pozakodeksowe prawo handlowe. Komentarz, t. 5, red. S. Sołtysiński, A. Szajkowski, A. Szumański, J. Szwaja, 2015, Legalis).

Postanowienia zarządzające wpis do rejestru dłużników niewypłacalnych są orzeczeniami kończącymi postępowanie co do istoty sprawy, od których, przed zmianą wprowadzoną ustawą nowelizującą, zgodnie z art. 518 k.p.c. uczestnikowi przysługiwała apelacja lub skarga na orzeczenie referendarza sądowego (art. $518^{1} \$ 3$ a w związku z art. 598 $22 \$ 1$ k.p.c.). Taka możliwość, zgodnie z art. 32 ustawy nowelizującej została przewidziana dla spraw, o których mowa w art. 55 ustawy o KRS, toczących się przed sądem rejestrowym wszczętych i niezakończonych do 15 marca 2018 r. W sprawach wszczynanych w okresie od 15 marca 2018 r. do 31 stycznia 2019 r. (wówczas to art. 55 i art. 57 ustawy o KRS utracą moc) postanowienia w przedmiocie wpisów do RDN nie są doręczane i nie podlegają zaskarżeniu.

4. Wskazaną przez autorów projektu ustawy nowelizującej ratio regulacji zawartej w art. 49 ustawy nowelizującej było wyeliminowanie nieefektywnego działania sądu, które w żaden sposób nie wpływa na „wzmocnienie wiarygodności i bezpieczeństwa obrotu”. Wprowadzona zmiana miała pozwolić „sądowi rejestrowemu skoncentrować jego aktywność na tym, co stanowi istotę jego działania, tj. rozpatrywaniu wniosków o wpis do rejestru przedsiębiorców i rejestru stowarzyszeń, innych organizacji społecznych i zawodowych, fundacji 
oraz samodzielnych publicznych zakładów opieki zdrowotnej" (uzasadnienie projektu ustawy, druk sejmowy nr 2067/VIII kad., s. 107). W uzasadnieniu projektu wskazano ponadto, że „dane ujawnione w RDN (zarówno na podstawie wpisów dokonanych przez sąd rejestrowy z urzędu, jak i na wniosek) nie cieszą się zainteresowaniem obrotu prawnego i gospodarczego". Projektodawcy uznają, że „dalsze prowadzenie tego rejestru nie wydaje się zatem celowe i uzasadnione”, a ponadto, „na podstawie art. 5 ust. $1 \mathrm{w}$ związku z art. 456 pkt 1 ustawy z dnia 15 maja 2015 r. - Prawo restrukturyzacyjne z dniem 1 lutego 2019 r. utworzony zostanie Centralny Rejestr Restrukturyzacji i Upadłości”, w którym powinny być zamieszczane „dane o osobach, o których mowa w art. 55 pkt 1, 1a, 2 i 4 ustawy o KRS" (ibidem, s. 94-95). W uzasadnieniu projektu stwierdzono ponadto: „Jak wynika z danych statystycznych zagrożenie wpisem do RDN nie stanowi dla dłużników alimentacyjnych czynnika motywującego do uregulowania należności. [...] Dziesięcioletni okres obowiązywania art. 55 pkt 5 ustawy o KRS i art. $1086 \$ 4$ k.p.c. pozwala na jednoznaczne stwierdzenie, że przyjęte w omawianych przepisach rozwiązanie nie doprowadziło do osiągnięcia zamierzonego rezultatu" (ibidem, s. 100). O nieskuteczności wpisów do rejestru dłużników niewypłacalnych Krajowego Rejestru Sądowego dla poziomu egzekucji świadczeń alimentacyjnych świadczą także wyniki ankiety przeprowadzonej przed opracowaniem projektu ustawy nowelizującej wśród urzędników odpowiedzialnych za postępowania wobec dłużników alimentacyjnych (ibidem).

\section{Stan faktyczny i zarzuty sądu}

1. Pod sygnaturą akt P 8/19 rozpatrywane są łącznie trzy pytania prawne Sądu Rejonowego XII Wydziału Gospodarczego Krajowego Rejestru Sądowego w Białymstoku z 2 lipca 2018 r. o sygn. akt: BI. XII Ns-Rej. KRS 4134/18/977; BI. XII Ns-Rej. KRS 3194/18/832; BI. XII Ns-Rej. KRS 4265/18/442.

2. Pierwsze pytanie prawne zostało sformułowane w następującym stanie faktycznym i prawnym. Przed sądem pytającym toczyło się postępowanie z urzędu o wpis dłużnika do RDN (sygn. akt BI. XII Ns-Rej. KRS 4134/18/977). Postępowanie to dotyczy osoby fizycznej, którą sąd prawomocnym postanowieniem, działając na podstawie art. 373 ust. 1 u.p.u., pozbawił na okres pięciu lat prawa prowadzenia działalności gospodarczej na własny rachunek oraz pełnienia funkcji członka rady nadzorczej, reprezentanta lub pełnomocnika w spółce handlowej, przedsiębiorstwie państwowym, spółdzielni, fundacji lub stowarzyszeniu. Sąd ten zasygnalizował Sądowi Rejonowemu potrzebę wpisania dłużnika do RDN jako osoby, w stosunku do której orzeczono prawomocny zakaz, o którym mowa w art. 373 ust. 1 u.p.u. Referendarz sądowy, postanowieniem z dnia 19 kwietnia 2018 r., działając z urzędu, na podstawie art. 55 ustawy o KRS, dokonał wpisu do RDN. Uczestnik postępowania w przewidzianym do tego terminie zaskarżył to postanowienie. Po rozpoznaniu sprawy na posiedzeniu niejawnym, sąd pytający przedstawił TK pytanie prawne. Wpłynęło ono do TK 27 sierpnia 
2018 r., 11 września 2018 r. uzupełnione zostały braki formalne. Sprawie nadano sygnaturę P 9/18.

3. Drugie pytanie prawne zostało sformułowane w następującym stanie faktycznym i prawnym. Przed sądem pytającym toczyło się postępowanie z urzędu o wpis dłużnika do RDN (sygn. akt BI. XII Ns-Rej. KRS 3194/18/832). Postępowanie to dotyczy osoby fizycznej, od której sąd wyrokiem z dnia 26 lutego 2008 r. zasądził na rzecz małoletniego alimenty w kwocie 100 złotych miesięcznie płatne do rąk matki dziecka, wraz z ustawowymi odsetkami w przypadku zwłoki. Następnie ów sąd wyrokami z 19 lipca 2010 r. i z 11 czerwca 2013 r. podwyższał kwotę należnych alimentów. Łączna wysokość zasądzonego zobowiązania alimentacyjnego dłużnika w okresie od 12 lutego 2008 r. do 2 lipca 2018 r. wynosiła 33848,28 zł. Wierzyciel, w związku z brakiem realizacji obowiązku alimentacyjnego w 2011 r. wszczął postępowanie egzekucyjne skierowane przeciwko zobowiązanemu, prowadzone przez Komornika Sądowego przy Sądzie Rejonowym w Białymstoku. Komornik ten 19 marca 2018 r. zasygnalizował sądowi pytającemu potrzebę wpisania do RDN dłużnika, który zalegał z zapłatą wymagalnych świadczeń pieniężnych przez okres ponad sześciu miesięcy. Referendarz, postanowieniem z dnia 9 kwietnia 2018 r. na podstawie art. 55 ustawy o KRS dokonał wpisu dłużnika do RDN. Uczestnik postępowania zaskarżył to orzeczenie, wnosząc o niewpisywanie go do RDN, zapewniając, że świadczenia alimentacyjne realizowane są na bieżąco poprzez zajęcie części przysługującej mu renty z tytułu całkowitej niezdolności do pracy. Po rozpoznaniu sprawy 2 lipca 2018 r. na posiedzeniu niejawnym sąd pytający, działając na podstawie art. 193 Konstytucji w związku z art. 52 ustawy z dnia 30 listopada 2016 r. o organizacji i trybie postępowania przed Trybunałem Konstytucyjnym (Dz. U. poz. 2072; dalej: ustawa o TK) przedstawił Trybunałowi pytanie prawne (sygn. akt BI.XII Ns-Rej. KRS 3194/18/832). Wpłynęło ono do TK 27 sierpnia 2018 r., 11 września 2018 r. uzupełnione zostały braki formalne. Sprawie nadano sygnaturę P 10/18. Z uwagi na tożsamość przedmiotu sprawy zarządzeniem Prezesa TK zostało ono połączone z pytaniem prawnym sądu pytającego z 2 lipca 2018 r., sygn. P 9/18, w celu łącznego rozpoznania pod wspólną sygnaturą $\mathrm{P}$ 9/18.

4. Trzecie pytanie prawne zostało sformułowane w następującym stanie faktycznym i prawnym. Przed sądem pytającym toczyło się postępowanie z urzędu o wpis dłużnika do RDN (sygn. akt BI.XII Ns-Rej. KRS 4265/18/442). Postępowanie to dotyczy osoby fizycznej, której sąd prawomocnym postanowieniem z dnia 12 lutego 2018 r., działając na podstawie art. 373 ust. 1 u.p.u., pozbawił na okres pięciu lat prawa prowadzenia działalności gospodarczej na własny rachunek oraz pełnienia funkcji członka rady nadzorczej, reprezentanta lub pełnomocnika w spółce handlowej, przedsiębiorstwie państwowym, spółdzielni, fundacji lub stowarzyszeniu. Sąd upadłościowy zasygnalizował sądowi pytającemu potrzebę wpisania dłużnika do RDN jako osoby, wobec której orzeczono prawomocny zakaz, o którym mowa w art. 373 ust. 1 u.p.u. Referendarz sądowy, dzia- 
łając $\mathrm{z}$ urzędu, postanowieniem z dnia 6 kwietnia $2018 \mathrm{r}$. dokonał wpisu dłużnika do RDN na podstawie art. 55 ustawy o KRS. Uczestnik postępowania zaskarżył to postanowienie. Po rozpoznaniu sprawy 2 lipca 2018 r. sąd pytający, działając na podstawie art. 193 Konstytucji, w związku z art. 52 ustawy o TK przedstawił Trybunałowi pytanie prawne. Pytanie to wpłynęło do TK 27 sierpnia 2018 r., 11 września 2018 r. uzupełnione zostały braki formalne. Sprawie nadano sygnaturę P 11/18. Zarządzeniem Prezesa TK, z uwagi na tożsamość przedmiotu sprawy, wyżej wskazane pytanie prawne zostało połączone z pytaniem prawnym tożsamego sądu z 2 lipca 2018 r., sygn. P 9/18, i pytaniem prawnym z 2 lipca 2018 r., sygn. P 10/18, w celu łącznego rozpoznania pod wspólną sygnaturą P 9/18.

5. Sąd pytający powziął wątpliwość co do zgodności art. 49 ustawy nowelizującej w zakresie dotyczącym art. 55 ustawy o KRS z art. 2, art. 31 ust. 3, art. 45 ust. 1 i ust. 2, art. 47 i art. 51 ust. 2 i ust. 4 Konstytucji.

Po pierwsze, $\mathrm{w}$ ocenie tego sądu, postępowania nieprocesowe, o których mowa w art. 55 ustawy o KRS, wszczęte z urzędu już w nowym stanie prawnym (tj. po 15 marca 2018 r.) ,przebiegają niejako inkwizycyjnie i kapturowo”, a z perspektywy uczestnika postępowania „sąd rejestrowy działa po kryjomu i skrycie” (uzasadnienia do trzech postanowień sądu pytającego z 2 lipca 2018 r.). Tym samym „uczestnik postępowania [...] nie tyle zostaje ograniczony w prawach strony postępowania, co zostaje pozbawiony takich praw" (ibidem).

Po drugie, sąd pytający wskazuje, że przyjęta redakcja przepisu wyrażającego normę prawną zawartą $\mathrm{w}$ art. 49 ustawy nowelizującej może prowadzić do sytuacji, w których orzeczenia o wpisie do rejestru dłużników niewypłacalnych mogą zapadać nawet bez pisemnego uzasadnienia. Po nowelizacji osoby mogą być wpisywane do RDN bez ich wiedzy i możliwości przedstawienia kontrargumentów w ramach postępowania sądowego kończącego się wpisem do rejestru.

Po trzecie, trudno mówić o skutecznym zagwarantowaniu obywatelowi możliwości ochrony czci i dobrego imienia w sytuacji, w której fakt wpisania obywatela do RDN może być przed nim ukryty, podczas gdy ma on sui generis penalny charakter, co znajduje potwierdzenie w przytaczanym $\mathrm{w}$ pytaniu prawnym orzecznictwie. Osoby ujawnione w RDN dotyka stygmatyzacja i w opinii sądu pytającego przy takim charakterze wpisu czynienie tego bez wiedzy i możliwości obrony uczestnika postępowania budzi co najmniej uzasadnione wątpliwości.

Po czwarte, zdaniem sądu pytającego, ,art. 49 ustawy nowelizującej godzi w cały szereg praw obywatelskich począwszy od prawa do sprawiedliwego i jawnego postępowania sądowego, przez prawo do ochrony czci i dobrego imienia, a zakończywszy na prawie do ochrony informacji o sobie (art. 51 ust. 2 i ust. 4 Konstytucji) poprzez zbieranie i ewidencjonowanie przez Państwo bez wiedzy obywatela, w zasadzie bez żadnej kontroli (przynajmniej drugiej instancji) określonych danych, umieszczanych w jawnych i ogólnodostępnych zbiorach, narażając tym samym obywatela na publiczne, społeczne potępienie" (ibidem). Sąd wskazuje, że w obrębie gwarancji prawa do sprawiedliwego postępowania sądowego 
„absolutnym minimum jest możliwość zajęcia przez stronę stanowiska w sprawie oraz możliwość zaskarżenia orzeczenia, które zdaniem uczestnika postępowania godzi w jego cześć, dobre imię oraz prawo do ochrony informacji” (ibidem).

Sąd pytający podkreślił także, że „skoro ustawodawca utrzymał rangę spraw o wpis osób do RDN jako spraw (postępowań) sądowych, to powinien być konsekwentny i utrzymać wszelkie standardy, jakie do postępowań sądowych w demokratycznym państwie powinny być stosowane" (ibidem). Nie zgodził się $\mathrm{z}$ argumentacją przedstawianą $\mathrm{w}$ uzasadnieniu projektu ustawy nowelizującej, zgodnie z którą uczestnicy postępowania rejestrowego są pozbawieni prawa do jawnego i sprawiedliwego postępowania sądowego ze względu na fakt, że jest ono prostym następstwem poprzednio prowadzonych, odrębnych postępowań sądowych. Podnosi, iż postępowanie rejestrowe, o którym mowa w art. 55 pkt 5 ustawy o KRS, nie opiera się bezpośrednio na orzeczeniu sądowym, a na okoliczności faktycznej stwierdzanej każdorazowo samodzielnie przez komornika sądowego, a zatem ustalenia te nie cieszą się powagą orzeczenia sądowego i, co więcej, czasem mogą odbiegać od rzeczywistości (ibidem). Niezależnie od tego, „prawomocne orzeczenie sądowe, będące podstawą wpisu osoby do RDN nierzadko w chwili dokonywania wpisu nie istnieje lub nie może być podstawą wpisu" (ibidem).

6. Na podstawie art. 63 ust. 2 oraz art. 43 pkt 10 ustawy o TK oraz art. 16 ust. 1 pkt 3 ustawy o Rzeczniku Praw Obywatelskich (t.j. Dz. U. 2018, poz. 2179) Rzecznik Praw Obywatelskich zgłosił udział w postępowaniu toczącym się przed TK pod sygn. P 9/18 w sprawie połączonych do wspólnego rozpoznania pytań prawych Sądu Rejonowego.

\section{Analiza formalna}

1. Pytania prawne Sądu Rejonowego budzą wątpliwości formalne, które wymagają wyjaśnienia przed przystąpieniem do oceny zgodności wskazanych norm ustawy z Konstytucją. Sejm zwraca uwagę w szczególności na przesłanki dopuszczalności pytania prawnego, które w swoim orzecznictwie wielokrotnie akcentował Trybunał Konstytucyjny (zob. postanowienie TK z 11 lutego 2015 r., sygn. akt P 44/13 i przywołane tam orzecznictwo). Zachowują one aktualność również pod rządami obecnie obowiązującej ustawy o TK, gdyż wynikają w pierwszym rzędzie z treści art. 193 Konstytucji (zob. wyrok TK z 18 października 2016 r., sygn. akt P 123/15).

2. W myśl art. 193 Konstytucji każdy sąd może przedstawić Trybunałowi Konstytucyjnemu pytanie prawne co do zgodności aktu normatywnego z Konstytucją, ratyfikowanymi umowami międzynarodowymi lub ustawą, jeżeli od odpowiedzi na to pytanie zależy rozstrzygnięcie sprawy toczącej się przed sądem. Pytanie prawne powinno spełniać łącznie trzy przesłanki: podmiotową, przedmiotową i funkcjonalną. Przesłanki te są rozumiane w orzecznictwie sądu konstytucyjnego w ten sposób, że: 
- pytanie prawne może być zadane wyłącznie przez sąd w rozumieniu art. 175 Konstytucji (postanowienie TK z 4 października 2010 r., sygn. akt P 12/08), czyli państwowy organ władzy sądowniczej, oddzielony i niezależny od władzy ustawodawczej i wykonawczej (postanowienie TK z 27 kwietnia 2004 r., sygn. akt P 16/03),

- przedmiotem pytania prawnego może być zgodność każdego aktu normatywnego (a więc aktu zawierającego normy prawne o charakterze generalnym i abstrakcyjnym; zob. postanowienie TK z 29 marca 2000 r., sygn. akt P 13/99) $\mathrm{z}$ przepisami, które mają wyższą rangę $\mathrm{w}$ hierarchicznym systemie prawa niż akt normatywny poddawany kontroli ( $\mathrm{w}$ zależności od sytuacji, mogą to być przepisy Konstytucji, ratyfikowanej umowy międzynarodowej lub ustawy; np. postanowienie TK z 6 października 2009 r., sygn. akt P 77/08),

- powinna istnieć zależność między odpowiedzią na pytanie a rozstrzygnięciem sprawy toczącej się przed pytającym sądem (postanowienia TK z: 29 marca 2000 r., sygn. akt P 13/99; 12 kwietnia 2000 r., sygn. akt P 14/99; 10 października 2000 r., sygn. akt P 10/00; 27 kwietnia 2004 r., sygn. akt P 16/03; 4 października 2010 r., sygn. akt P 12/08) polegająca na tym, że od odpowiedzi na pytanie prawne musi zależeć rozstrzygnięcie konkretnej sprawy toczącej się przed sądem pytającym (np. postanowienia TK z: 22 października 2007 r., sygn. akt P 24/07, oraz 15 kwietnia 2008 r., sygn. akt P 26/07).

W orzecznictwie TK wskazywano przy tym, że przedmiotem sprawy może być wyłącznie przepis (proceduralny, materialnoprawny lub kompetencyjny), który powinien być zastosowany przez sąd $\mathrm{w}$ toczącym się postępowaniu i na podstawie którego sąd jest zobowiązany wydać stosowne orzeczenie, a więc przepis, który będzie stanowił podstawę rozstrzygnięcia (zob. powołane postanowienie TK w sprawie o sygn. akt P 12/08, i postanowienia TK z: 27 lutego 2008 r., sygn. akt P 31/06, oraz 19 października 2011 r., sygn. akt P 42/10). Trybunał Konstytucyjny, przyjmując pytanie prawne do rozpoznania, bada, czy jego wypowiedź dotycząca konstytucyjności przepisu będzie miała wpływ na wynik sprawy. Artykuł 52 ust. 2 pkt 5 ustawy o TK nakłada na sąd pytający obowiązek wskazania, w jakim zakresie odpowiedź na pytanie może mieć wpływ na rozstrzygnięcie sprawy, w związku z którą pytanie zostało przedstawione. „Dopełnienie tego obowiązku nie następuje przez powtórzenie ogólnej formuły ustawowej, ale wymaga wykazania, że in casu spełniony jest konstytucyjny warunek dopuszczalności pytania prawnego" (postanowienie TK z 13 lutego 2012 r., sygn. akt P 5/09). Wyjaśnienie zakresu, w którym odpowiedź na pytanie prawne może mieć wpływ na rozstrzygnięcie sprawy, powinno obejmować elementy podkreślające znaczenie wyroku TK dla sprawy zawisłej przed sądem, „[...] nie chodzi tu jednak o uzasadnienie zarzutu niezgodności z Konstytucją (lub powołanie dowodów na jego poparcie), ale o sui generis uzasadnienie dopuszczalności pytania prawnego. Niezależnie od tego stwierdzić jednak należy, że na sądzie składającym pytanie 
prawne ciąży powinność stosownego do charakteru sprawy odrębnego wskazania, w jaki sposób rozstrzygnięcie sądu uległoby zmianie, gdyby określony przepis prawny utracił moc obowiązującą wskutek orzeczenia przez Trybunał Konstytucyjny o jego niezgodności z Konstytucją" (wyrok TK z 7 listopada 2005 r., sygn. akt P 20/04).

3. Nie ulega wątpliwości, że w rozpatrywanych przypadkach została spełniona przesłanka podmiotowa. Z pytaniem prawnym do TK wystąpił sąd w ramach toczących się przed nim postępowań.

4. W końcowych akapitach uzasadnień trzech postanowień o postawieniu Trybunałowi Konstytucyjnemu pytań prawnych sąd pytający odnosi się do związku funkcjonalnego między odpowiedzią na przedstawiane pytania a rozstrzygnięciem rozpatrywanych spraw. Sąd „zdecydował się przedstawić Trybunałowi Konstytucyjnemu pytanie prawne, ponieważ ewentualne uznanie art. 49 ustawy nowelizującej za niezgodny z Konstytucją Rzeczypospolitej Polskiej będzie oznaczać konieczność merytorycznego rozpoznania skargi uczestnika postępowania na postanowienia Referendarza Sądowego przy Sądzie Rejonowym w Białymstoku [...] a nie jej odrzucenie jako niedopuszczalnej" (uzasadnienia trzech postanowień sądu pytającego z 2 lipca 2018 r.).

Wyeliminowanie $\mathrm{z}$ systemu prawnego zakwestionowanego przepisu doprowadzi do sytuacji, w której na postanowienie zarządzające wpis do RDN wydane z urzędu w sprawach wszczętych po dniu 15 marca 2018 r. uczestnikowi postępowania będzie przysługiwała apelacja do sądu drugiej instancji na podstawie art. 518 k.p.c. lub skarga na orzeczenie referendarza sądowego na podstawie art. $518^{1} \S 3 \mathrm{a}$ w związku z art. $398^{22} \S 1$ k.p.c.

W każdym z pytań prawnych wskazana została konkretna data wydania postanowienia referendarza sądowego w przedmiotowej kwestii, a także określona podstawa dokonania wpisu do RDN. Sejm podziela stanowisko sądu pytającego, że występuje związek funkcjonalny między kwestionowaną regulacją a rozstrzygnięciem skargi uczestnika postępowania na postanowienie referendarza sądowego o dokonaniu wpisu do RDN, ale jedynie w zakresie obejmującym podstawę dokonania konkretnych wpisów. W przypadku pierwszego i trzeciego pytania prawnego tę podstawę stanowi art. 55 pkt 4 ustawy o KRS, w przypadku pytania drugiego będzie to art. 55 pkt 5 ustawy o KRS. W odniesieniu do tych podstaw prawnych spełniony jest wymóg, by rozstrzygnięcie w konkretnej, toczącej się przed sądem sprawie było zależne od odpowiedzi na pytanie prawne, od tego czy wskazane przepisy utracą moc obowiązującą wskutek orzeczenia przez Trybunał o ich niezgodności z Konstytucją (zob. wyrok TK z 21 stycznia 2014 r., sygn. akt P 26/12). Jedynie w odniesieniu do art. 49 ustawy nowelizującej w związku z art. 55 pkt 4-5 ustawy o KRS sąd pytający wykazał, w jaki sposób wyrok TK (ewentualne orzeczenie o niekonstytucyjności) mógłby oddziaływać na sytuację prawną uczestnika postępowania w sprawach, w których przedstawił Trybunałowi pytanie prawne. Z uwagi na wskazaną wcześniej konieczność 
spełnienia przesłanki funkcjonalnej Sejm ograniczy swoje stanowisko do kwestii zgodności z Konstytucją art. 49 wyłącznie w tym zakresie. W pozostałym zakresie przesłanka ta nie jest spełniona i postępowanie powinno zostać umorzone.

5. Do rozważenia pozostaje także kwestia spełnienia przesłanki przedmiotowej przez przedstawione przez Sąd Rejonowy pytanie prawne. W pytaniu sąd sformułował zarzuty w ten sposób, że określił zaskarżony przepis oraz wskazał wzorce kontroli. Istotne wątpliwości budzi sposób uzasadnienia zachodzącej sprzeczności między normą ustawową a niektórymi ze wskazanych norm konstytucyjnych. Zgodnie $\mathrm{z}$ art. 52 ust. 2 pkt 4 ustawy o TK pytanie prawne powinno zawierać uzasadnienie postawionego zarzutu, z powołaniem argumentów lub dowodów na jego poparcie. W orzecznictwie sądu konstytucyjnego konsekwentnie podkreśla się, że prawidłowy wniosek powinien zawierać szczegółową i precyzyjną jurydyczną argumentację uprawdopodabniającą stawiane zarzuty (zob. np. postanowienia TK z: 17 listopada 2011 r., sygn. akt Ts 40/11; 2 lutego 2012 r., sygn. akt Ts 93/11). Wymogu tego nie spełniają uwagi nazbyt ogólne, niejasne czy też czynione jedynie na marginesie innych rozważań (zob. np. wyrok TK z 5 czerwca 2014 r., sygn. akt K 35/11; postanowienie TK z 13 stycznia 2015 r., sygn. akt K 44/13). „Wobec respektowania generalnej zasady, jaką jest domniemanie konstytucyjności aktu normatywnego, samo wskazanie w petitum wzorca kontroli, bez szczegółowego odniesienia się w uzasadnieniu do kwestionowanej regulacji prawnej lub lakoniczne sformułowanie zarzutu niekonstytucyjności nie może zostać uznane za «uzasadnienie postawionego zarzutu, z powołaniem dowodów na jego poparcie» w rozumieniu przepisów regulujących postępowanie przed Trybunałem Konstytucyjnym. W świetle utrwalonej praktyki orzeczniczej wymóg ten należy rozumieć jako nakaz odpowiedniego udowodnienia zarzutów stawianych w kontekście każdego wskazanego wzorca kontroli” (postanowienia TK z: 21 stycznia 2015 r., sygn. akt K 13/13; 30 października 2018 r., sygn. akt P 15/16).

W niniejszej sprawie sąd pytający uczynił wzorcami kontroli art. 2, art. 31 ust. 3 , art. 45 ust. 1 i ust. 2, art. 47 i art. 51 ust. 2 i ust 4 Konstytucji. Z wyjątkiem jednak art. 45 ust. 1 względem pozostałych artykułów ustawy zasadniczej wywód argumentacyjny sądu ogranicza się do stwierdzenia, że „art. 49 godzi w cały szereg praw obywatelskich" oraz ich wyliczenia. W efekcie pytania prawne pozbawione są czytelnego i logicznego powiązania treści zaskarżonego przepisu z poszczególnymi artykułami Konstytucji jako wzorcami kontroli. Sąd ograniczył się do lakonicznych stwierdzeń o charakterze generalizacji potocznych, wprost przesądzając, że „nie zamierza szerzej wyjaśniać na czym powinno wyglądać sprawiedliwe postępowanie sądowe”. Takie ujęcie problemu nie czyni zadość obowiązkowi uzasadnienia zarzutów pytania prawnego. Pytanie prawne nie zawiera oddzielnego wywodu przemawiającego za uchyleniem domniemania konstytucyjności zaskarżonego przepisu w odniesieniu do wskazanych w pytaniach prawnych wzorców kontroli. 
Mając powyższe na względzie, Sejm wnosi o umorzenie postępowania przed Trybunałem Konstytucyjnym w zakresie badania zgodności art. 49 ustawy nowelizującej z art. 2, art. 45 ust. 2, art. 47 i art. 51 ust. 2 i ust 4 Konstytucji, na podstawie art. 59 ust. 1 pkt 2 ustawy o TK, z uwagi na niedopuszczalność wydania wyroku. Wzorzec konstytucyjności, który zostanie poddany analizie w dalszej części stanowiska, to wyłącznie art. 45 ust. 1 Konstytucji, ponieważ jedynie w tym zakresie pytanie prawne zawiera w wystarczającym stopniu szczegółową i precyzyjną jurydyczną argumentację uprawdopodabniającą stawiane zarzuty.

\section{Wzorzec kontroli}

1. Konstytucja w art. 45 ust. 1 przewiduje, iż: „Każdy ma prawo do sprawiedliwego i jawnego rozpatrzenia sprawy bez nieuzasadnionej zwłoki przez właściwy, niezależny, bezstronny i niezawisły sąd”. Istota prawa do sądu sprowadza się do zapewnienia ochrony sądowej w sprawach dotyczących sfery praw lub wolności danego podmiotu. Prawo do sądu stanowi jedno z podstawowych praw jednostki i jedną z fundamentalnych gwarancji praworządności. Wedle utrwalonego orzecznictwa Trybunału Konstytucyjnego obejmuje ono:

- prawo dostępu do sądu, tj. prawo uruchomienia postępowania przed sądem organem o określonej charakterystyce (właściwym, niezależnym, bezstronnym i niezawisłym),

- prawo do właściwej procedury przed sądem,

- prawo do wiążącego rozstrzygnięcia sprawy (wyroki TK z: 9 czerwca 1998 r., sygn. akt K 28/97; 10 lipca 2000 r., sygn. akt SK 12/99; stanowisko to zostało wielokrotnie powtórzone w późniejszym orzecznictwie).

W 2007 r. TK uzupełnił te elementy prawa do sądu o „prawo do odpowiedniego kształtowania ustroju i pozycji organów rozpoznających sprawy" (wyrok z 24 października 2007 r., sygn. akt SK 7/06). Stanowisko to pojawia się w nowszej judykaturze, w której wyodrębnia się cztery elementy prawa do sądu (np. wyroki TK z: 6 listopada 2012 r., sygn. akt K 21/11; 15 kwietnia 2014 r., sygn. akt SK 12/13; 30 września 2014 r., sygn. akt SK 22/13; 13 stycznia 2015 r., sygn. akt SK 34/12). Trybunał podkreślił także, że „w państwie prawnym prawo do sądu nie może być rozumiane jedynie formalnie, jako dostępność drogi sądowej w ogóle, lecz i materialnie, jako możliwość prawnie skutecznej ochrony praw na drodze sądowej [...]”. Podobne stanowisko zajął Sąd Najwyższy, według którego prawo do sądu nie wygasa w momencie złożenia powództwa i podjęcia na tej podstawie procesu, ale chodzi w nim o to, aby sąd rozpoznał sprawę co do jej istoty (postanowienie SN z 19 lipca 2006 r., sygn. akt I CSK 112/06).

2. Konstytucyjne prawo do sądu ma aspekt pozytywny, zawiera bowiem dyrektywy, zobowiązujące ustawodawcę do należytego ukształtowania systemu wymiaru sprawiedliwości w wymiarze instytucjonalnym i proceduralnym oraz zapewnienia jego efektywnego funkcjonowania. W tym aspekcie można mó- 
wić o obowiązku ustawodawcy ustanowienia regulacji prawnej, która zapewnia rozpatrzenie sprawy przez sąd, na żądanie zainteresowanego. Negatywny aspekt prawa do sądu wyraża się w zakazie zamykania lub nadmiernego ograniczania dostępu do wymiaru sprawiedliwości (art. 45 ust. 1 w związku $\mathrm{z}$ art. 77 ust. 2 Konstytucji). Fundamentalnym założeniem Konstytucji jest jej aksjologiczna i teleologiczna spójność, dlatego też dyrektywa zakazująca zamykania drogi sądowej musi być uwzględniana w procesie wykładni ogólnej zasady prawa do sądu (wyroki TK z: 9 czerwca 1998 r., sygn. akt K 28/97; 15 października 2001 r., sygn. akt K 12/01; 7 września 2004 r., sygn. akt P 4/04; 29 stycznia 2013 r., sygn. akt SK 28/11).

Trybunał Konstytucyjny w swoim orzecznictwie podkreślił, że z prawa do sądu wynika prawo do zastosowania sprawiedliwej procedury, tj. takiej, która „powinna zapewniać stronom uprawnienia procesowe stosowne do przedmiotu prowadzonego postępowania. Wymóg sprawiedliwego postępowania zakłada bowiem dostosowanie jego zasad do specyfiki rozpoznawanych spraw" (wyrok TK z 16 listopada 2011 r., sygn. akt SK 45/09). Prawo do odpowiedniego ukształtowania postępowania ma charakter uniwersalny w tym sensie, że dotyczy każdego rodzaju postępowania sądowego, które objęte jest gwarancjami składającymi się na prawo do sądu (zob. wyrok TK z 12 lipca 2011 r., sygn. akt SK 49/08). Obowiązuje więc niezależnie od rodzaju załatwianej sprawy, jeżeli tylko ustawodawca powierza jej rozpoznanie sądowi przedmiotu sprawy (praw lub obowiązków, których dotyczy), sposobu jej wszczęcia (na żądanie zainteresowanego podmiotu, organu publicznego albo z urzędu) oraz etapu, na którym znajduje się rozstrzygana sprawa (zob. wyroki TK z: 12 stycznia 2010 r., sygn. akt SK 2/09; 11 maja 2011 r., sygn. akt SK 11/09; 12 lipca 2011 r., sygn. akt SK 49/08). Ustawodawca jest uprawniony do różnicowania postępowań sądowych w zależności od ich charakteru, przedmiotu rozpoznawanych w nich spraw, znaczenia dochodzonych w nich praw i obowiązków dla zainteresowanych podmiotów, celów realizowanych $\mathrm{w}$ ramach tych postępowań, zakresu kognicji sądu, a także etapu, na którym znajduje się rozstrzygana sprawa (zob. wyroki TK z: 13 stycznia 2004 r., sygn. akt SK 10/03; 28 lipca 2004 r., sygn. akt P 2/04; 26 stycznia 2005 r., sygn. akt P 10/04; 20 października 2010 r., sygn. akt P 37/09; 16 listopada 2011 r., sygn. akt SK 45/09).

3. Ocena konstytucyjności tych szczegółowych rozwiązań i wyłaniającego się z nich kształtu określonego rodzaju postępowania sądowego wymaga odniesienia tego kształtu do wymagań konstytucyjnych w ujęciu całościowym (zob. wyrok TK z: 28 lipca 2004 r., sygn. akt P 2/04; 26 stycznia 2005 r., sygn. akt P 10/04; 20 października 2010 r., sygn. akt P 37/09; 16 listopada 2011 r., sygn. akt SK 45/09). Prawo do różnicowania postępowań sądowych w zależności od ich charakteru nie oznacza arbitralności w stanowieniu przepisów proceduralnych, przykładowo takich, które ponad miarę, a więc bez wystąpienia istotnych racji, ograniczają prawa procesowe strony (zob. wyroki TK z: 20 października 
2010 r., sygn. akt P 37/09; 16 listopada 2011 r., sygn. akt SK 45/09). Wymagane jest zapewnienie sprawiedliwości proceduralnej, która, jak wskazuje TK, stanowi gwarancję tego, aby prawo do sądu nie było prawem fasadowym (zob. wyroki TK Z: 26 lutego 2008 r., sygn. akt SK 89/06; 29 kwietnia 2008 r., sygn. akt SK 11/07; 20 października 2010 r., sygn. akt P 37/09).

Konstytucyjny nakaz sprawiedliwego rozpatrzenia sprawy zawiera w sobie trzy podstawowe gwarancje (zob. wyroki TK z: 31 marca 2005 r., sygn. akt SK 26/02; 16 stycznia 2006 r., sygn. akt SK 30/05; 2 października 2006 r., sygn. akt SK 34/06; 20 listopada 2007 r., sygn. akt SK 57/05; 26 lutego 2008 r., sygn. akt SK 89/06; 12 stycznia 2010 r., sygn. akt SK 2/09; 18 października 2011 r., sygn. akt SK 39/09; 8 kwietnia 2014 r., sygn. akt SK 22/11):

- możność bycia wysłuchanym (prawo do wysłuchania),

- ujawnienie w czytelny sposób motywów rozstrzygnięcia (prawo do uzasadnienia lub szerzej - prawo do informowania),

- zapewnienie przewidywalności postępowania (prawo do przewidywalności postępowania; we wcześniejszym orzecznictwie wskazywano także na prawo do przewidywalności rozstrzygnięcia - zob. wyrok TK z 17 października 2000 r., sygn. akt SK 5/99).

4. Zarówno w orzecznictwie Trybunału Konstytucyjnego, jak i w doktrynie prawa jest bezsporne, że prawo do sądu nie ma charakteru absolutnego. Tytułem przykładu można przywołać wyrok Trybunału z 10 maja 2000 r. (sygn. akt SK 21/99), w którym podkreślono, że: „[...] nie istnieje w żadnym systemie prawnym bezwzględne i absolutne prawo do sądu - które nie podlegałoby jakimkolwiek ograniczeniom i które w konsekwencji stwarzałoby uprawnionemu nieograniczoną możliwość ochrony swych praw na drodze sądowej. To stwierdzenie należy odnieść do wszystkich kategorii praw, bowiem samo ukształtowanie postępowania przed sądem w sposób respektujący określone procedury [...] stanowi istotne i rzeczywiste ograniczenie prawa do sądu, konieczne jednak ze względu na inne wartości powszechnie szanowane w państwie prawnym, jak w szczególności bezpieczeństwo prawne, zasada legalizmu czy zaufanie do prawa" (zob. także wyroki TK z: 7 września 2004 r., sygn. akt P 4/04 i 16 grudnia 2008 r., sygn. akt P 17/07). W opinii Trybunału Konstytucja nie wyklucza ustanawiania w ustawie ograniczeń prawa do sądu, jeżeli nie prowadzą do zamknięcia sądowej drogi dochodzenia konstytucyjnych wolności i praw oraz mieszczą się w ramach określonych przez art. 31 ust. 3 Konstytucji, wyznaczający granice ingerencji organów władzy publicznej w tej sferze (zob. wyrok TK z 12 września 2006 r., sygn. akt SK 21/05).

\section{Analiza zgodności}

1. Postępowanie w sprawie o wpis do rejestru dłużników niewypłacalnych jest postępowaniem rejestrowym $w$ rozumieniu art. $519^{1} \$ 3$ k.p.c. (zob. postanowie- 
nie SN z 27 kwietnia 2006 r., sygn. akt I CZ 18/06). Rejestr dłużników niewypłacalnych wchodzi w skład KRS. Co do zasady wpisowi z urzędu do tego rejestru na podstawie art. 55 ustawy o KRS podlegają osoby fizyczne, jak też osoby prawne lub jednostki organizacyjne mające zdolność prawną. Są to przeważnie podmioty, które znalazły się w złej sytuacji finansowej, lub osoby, które z powodu popełnionych czynów pozbawiono prawa uczestniczenia w życiu gospodarczym jako przedsiębiorca albo sprawowania określonych funkcji związanych z prowadzeniem działalności gospodarczej, przy czym warunkiem wpisu jest również spełnienie kryteriów wskazanych w art. 55 lub art. 56 ustawy o KRS. W pierwszej kolejności ustawa wskazuje osoby prowadzące działalność gospodarczą indywidualnie i bezpośrednio (art. 55 pkt 1 i 4) lub wspólnie w formie spółki osobowej (art. 55 pkt 2) bądź osoby, które zostały pozbawione prawa sprawowania funkcji członka organu lub przedstawiciela w spółce handlowej, przedsiębiorstwie państwowym lub spółdzielni. Od 31 grudnia 2014 r. wpisowi do RDN podlegają ponadto osoby fizyczne nieprowadzące działalności gospodarczej, jeżeli ogłoszono ich upadłość.

2. W uzasadnieniu postanowienia z 19 lutego 2003 r., sygn. akt V CK 7/03, Sąd Najwyższy stwierdził, że rejestr dłużników niewypłacalnych spełnia funkcję ewidencyjną i informacyjną. Ustawodawca przesądził, że rejestr ten korzysta $\mathrm{z}$ domniemania prawdziwości wpisanych do niego danych. $\mathrm{Z}$ tej przyczyny podstawą wpisu są dane zweryfikowane prawomocnym orzeczeniem sądowym, zarówno przy wpisie z urzędu, jak i na wniosek wierzyciela. Rejestr pełni rolę informacyjną i jest instrumentem prawnym, który pozwala na pozyskanie wiedzy o potencjalnych kontrahentach (zob. N. Kowal [w:] L. Ciulkin, A. Jakubecki, N. Kowal, Krajowy Rejestr Sądowy i postępowanie rejestrowe. Praktyczny komentarz, Warszawa 2002, s. 178-179). Instrument ten ma ograniczać ryzyko inwestycyjne. Jest to „rozwiązanie prawne, chroniące potencjalnego wierzyciela przed niewypłacalnością dłużnika jeszcze przed powstaniem zobowiązania. Sąd Najwyższy zwrócił uwagę, że rejestr dłużników niewypłacalnych został powołany w interesie wierzycieli (inwestorów). Wpis do rejestru ujawnia podmioty niewiarygodne, niezasługujące na zaufanie w obrocie gospodarczym, a tym samym prowadzi do eliminowania ich $\mathrm{z}$ tego obrotu. Jest to korzystne dla sytuacji rynkowej, może natomiast realnie utrudnić osobom «napiętnowanym» wpisem do RDN reaktywowanie działalności gospodarczej. Zatem nie element subiektywny w postaci winy (potencjalnego) kontrahenta ma znaczenie dla osób zainteresowanych informacjami ujawnionymi w tym rejestrze, lecz obiektywny stan majątkowy, sytuacja ekonomiczna danego podmiotu. W równej mierze należy więc umożliwić dostęp do informacji o dłużnikach nieuczciwych, jak też o tych, którzy przez swoją nieporadność narazili interesy innych podmiotów, występujących w obrocie gospodarczym (por. N. Kowal, w: L. Ciulkin, A. Jakubecki, N. Kowal, Krajowy Rejestr Sądowy, s. 179)" (M. Tarska, Komentarz do art. 55 ustawy, op. cit.). 
3. W literaturze funkcjonuje pogląd, że wpis do RDN stanowi szczególną sankcję dla osoby, która została w nim ujawniona (zob. m.in. T. Palmirski, Wpis do Rejestru Dłużników Niewypłacalnych na zasadzie art. 55 ustawy o Krajowym Rejestrze Sadowym. Stan aktualny - uwagi de lege ferenda, „Rejent” 2009, nr 5, s. 98 i n.). Konstrukcja normatywna rejestru pozwala bowiem stwierdzić, że są w nim ujawnieni dłużnicy niesolidni, przed którymi, niezależnie od ich indywidualnego zawinienia, należy ostrzegać potencjalnych kontrahentów (idem, Rejestr dłużników niewypłacalnych, „Zeszyty Prawnicze UKSW” 2009, t. 9, s. 280). Figurowanie w RDN stanowi więc szczególny przypadek napiętnowania osoby fizycznej czy prawnej, które następuje przez podanie do publicznej wiadomości określonych informacji dotyczących jej zadłużenia lub niesolidności jako dłużnika.

Podobnie zapatruje się na tę kwestie orzecznictwo: „wpis do takiego rejestru ma informować uczestników obrotu o podmiotach, które ze względu na swoją sytuację majątkową stanowią potencjalne zagrożenie dla kontrahentów [...] Z punktu widzenia samego dłużnika pełni on niewątpliwie rolę swoistej sankcji, która spotyka go za to, że nie realizuje zobowiązań wobec wierzycieli" (uchwała Sądu Najwyższego z 16 marca 2007 r., sygn. akt III CZP 9/07). W uzasadnieniu uchwały z 19 sierpnia 2009 r., sygn. akt III CZP 46/09, Sąd Najwyższy wprost stwierdza, że „wpis do rejestru dłużników niewypłacalnych ma charakter sankcji za niespełnienie świadczenia w terminie".

4. W uzasadnieniu projektu ustawy nowelizującej przedstawionego Sejmowi w piśmie z 23 listopada 2017 r., obowiązujące wówczas przepisy ustawy o KRS uznane zostały za regulację „niewystarczającą, nieuwzględniającą nowych rozwiązań prawnych i technicznych”, co w ocenie projektodawcy może „z biegiem lat prowadzić do znacznego obniżenia efektywności działania sądu rejestrowego oraz wiarygodności rejestru" (uzasadnienie projektu ustawy nowelizującej, druk sejmowy nr 2067/VIII kad., s. 2). Potrzeba wprowadzenia nowych treści normatywnych do ustawy o KRS miała wynikać także z konieczności implementacji dyrektywy Parlamentu Europejskiego i Rady 2017/1132/UE z dnia 14 czerwca 2017 r. w sprawie niektórych aspektów prawa spółek (Dz. Urz. UE L 169 z 30 czerwca 2017 r.) w zakresie przepisów dotyczących systemu integracji rejestrów.

Jednym z kierunków zmian wprowadzanych przez ustawę nowelizującą było „uproszczenie dokonywania tzw. wpisów ewidencyjnych do rejestru przedsiębiorców oraz zmiana sposobu i zakresu ujawniania informacji o zaległościach płatniczych podmiotu” (ibidem, s. 4). Analizując kilkanaście lat funkcjonowania rejestru dłużników niewypłacalnych, projektodawca stwierdził, że RDN nie jest rejestrem, „który wzmacniałby pewność i bezpieczeństwo obrotu oraz pełnił funkcję informacyjną i ostrzegawczą o niesolidnych kontrahentach". Ponadto zauważył, iż „postępowania o wpis do RDN często są czasochłonne i wymagają nieproporcjonalnych nakładów (czasu pracy, jak i finansowych) w stosunku do osiąganych rezultatów, jak również w stosunku do zainteresowania społecznego danymi ujawnionymi w RDN" (ibidem, s. 86). 
Wedle uzasadnienia projektu za tzw. wpisy ewidencyjne uznawać należy wpisy, które polegają na „ujawnieniu w rejestrze informacji o orzeczeniach wydanych przez sąd lub organ administracyjny lub egzekucyjny (np. sąd upadłościowy, komornika). W tego typu sprawach sąd rejestrowy nie przeprowadza kontroli czynności leżących u podstaw wpisu, nie bada zasadności i poprawności wydania orzeczenia stanowiącego podstawę wpisu" (ibidem, s. 87). Przykładami wpisów ewidencyjnych w rejestrze przedsiębiorców są, w ocenie projektodawcy, wpisy w przedmiocie np.: informacji o zabezpieczeniu majątku dłużnika w postępowaniu w przedmiocie ogłoszenia upadłości, informacji o zawieszeniu prowadzonych przeciwko dłużnikowi egzekucji, informacji o oddaleniu wniosku o ogłoszenie upadłości na podstawie art. 13 ust. 1 ustawy z dnia 28 lutego 2003 r. - Prawo upadłościowe (art. 41 pkt 4 ustawy o KRS).

W stanie prawnym obowiązującym przed wejściem w życie ustawy nowelizującej, w przypadku wpisów ewidencyjnych wymagane było z reguły wydanie przez sąd postanowienia o wpisie do rejestru, jego uzasadnienie (postępowanie prowadzone jest bowiem z urzędu) i doręczenie uczestnikowi postępowania. Od postanowienia przysługiwał środek zaskarżenia. „W wielu tego typu postępowaniach, ze względu na brak informacji o miejscu pobytu uczestnika nie ma możliwości skutecznego doręczenia postanowienia o wpisie - zachodzi zatem konieczność ustanowienia kuratora, co generuje dodatkowe koszty i powoduje, że prosta z założenia sprawa staje się czasochłonna” (ibidem, s. 134).

Projektodawca podważył racjonalność takiego rozwiązania. Wskazał, że: „[j]ak wynika z wieloletniej praktyki orzeczniczej sądów rejestrowych, skargi lub apelacje składane od postanowień zarządzających (ewidencyjny) wpis do rejestru w rzeczywistości nie dotyczą decyzji sądu rejestrowego, a odnoszą się do orzeczenia stanowiącego podstawę wpisu do KRS. Strony podnoszą zarzuty dotyczące treści orzeczenia sądu lub innego organu i kwestionują przykładowo zasadność oddalenia wniosku o ogłoszenie upadłości. W takich przypadkach rozpoznanie skargi lub apelacji polega na wskazaniu w pisemnym uzasadnieniu, że sąd rejestrowy nie ingeruje w treść lub zasadność wydania orzeczenia stanowiącego podstawę dokonania wpisu do rejestru. Nie ma zatem potrzeby utrzymywania środków zaskarżenia od tego typu orzeczeń sądów rejestrowych, czyli od postanowień zarządzających wpis do rejestru treści rozstrzygnięcia innego sądu lub organu, gdyż orzeczenie sądu rejestrowego nie kształtuje żadnego nowego stanu. Gdyby jednak doszło do wpisu niedopuszczalnego (czego nie można wykluczyć), to po powzięciu informacji w tym zakresie, sąd rejestrowy jest zobowiązany wszcząć postępowanie z urzędu na podstawie aktualnie obowiązujących przepisów, w szczególności art. 12 ust. 3 ustawy o KRS” (ibidem, s. 90).

Zgodnie z treścią projektu ustawy nowelizującej do kategorii wpisów ewidencyjnych zostały zaliczone także wpisy, o których mowa w art. 55 ustawy o KRS (ibidem, s. 107). Taka ich kwalifikacja rzutowała na treść, jaką uzyskał art. 49 przepis przejściowy - zgodnie z którym, w sprawach wszczętych od dnia wejścia 
w życie ustawy nowelizującej postanowienia w przedmiocie wpisów, o których mowa w art. 55 ustawy o KRS, nie będą wymagały doręczenia i nie będą podlegały zaskarżeniu. W uzasadnieniu pojawia się argument, iż „postępowania o wpis do rejestru dłużników niewypłacalnych często są czasochłonne i wymagają nieproporcjonalnych nakładów (czasu pracy, jak i finansowych) w stosunku do osiąganych rezultatów, jak również w stosunku do zainteresowania społecznego danymi ujawnionymi w RDN” (ibidem, s. 86). Z kolei przyjęte w art. 49 rozwiązanie „wyeliminuje nieefektywne działania sądu, które w żaden sposób nie wpływają na wzmocnienie wiarygodności i bezpieczeństwa obrotu i pozwoli sądowi rejestrowemu skoncentrować jego aktywność na tym, co stanowi istotę jego działania, tj. rozpoznawanie wniosków o wpis do rejestru przedsiębiorców i rejestru stowarzyszeń, innych organizacji społecznych i zawodowych, fundacji oraz samodzielnych publicznych zakładów opieki zdrowotnej" (ibidem).

5. W piśmie Ministra Sprawiedliwości z 18 listopada 2014 r. do wicemarszałka Senatu (znak DPrC-III-4392-35/14) poświęconym wpisom do RDN w projektowanej nowelizacji ustawy o KRS pojawił się argument, iż „od postanowień zarządzających wpis do rejestru treści rozstrzygnięcia innego sąd lub organu nie ma potrzeby utrzymywania środków zaskarżenia, gdyż orzeczenie sądu rejestrowego nie kształtuje żadnego nowego stanu”, sąd dokonuje „technicznego ujawnienia określonej informacji w rejestrze".

6. Z uwagi na swoisty charakter postępowania w przedmiocie wpisu do RDN należy w pierwszej kolejności ustalić, czy mieści się ono w pojęciu „sprawy”, o której rozpatrzenie zgodnie z wymaganiami określonymi w art. 45 ust. 1 Konstytucji może ubiegać się podmiot uprawniony (zob. wyrok TK z 26 kwietnia 2005 r., sygn. akt SK 36/03). Wskazane pojęcie konstytucyjne jest nieostre, a określenie jego konturów zostało powierzone orzecznictwu i doktrynie. Trybunał od początku opowiadał się za wykładnią zmierzającą do objęcia art. 45 ust. 1 Konstytucji możliwie najszerszego zakresu spraw (wyroki z: 9 czerwca 1998 r., sygn. akt K 28/97; 8 listopada 2001 r., sygn. akt P 6/01; 8 października 2002 r., sygn. akt K 36/00; 18 października 2011 r., sygn. akt SK 39/09; 29 czerwca 2010 r., sygn. akt P 28/09). TK w zdecydowanej większości swoich orzeczeń, w których powstawała konieczność odpowiedzi na pytanie, czy konkretna sytuacja może być kwalifikowana jako sprawa w rozumieniu art. 45 ust. 1 Konstytucji, odpowiadał na to pytanie twierdząco. Pojęcie sprawy nie jest ograniczone do określonych dziedzin stosunków prawnych. Zakresem zastosowania art. 45 ust. 1 objęte są wszystkie podstawowe obszary systemu prawnego. TK podkreślił, że jest to pojęcie autonomiczne, którego nie można objaśniać wyłącznie przez odniesienia do pojęcia sprawy funkcjonującego na tle poszczególnych gałęzi prawa: karnego, cywilnego czy administracyjnego (zob. wyroki TK z: 12 maja 2003 r., sygn. akt SK 38/02; 18 maja 2004 r., sygn. akt SK 38/03; 27 maja 2008 r., SK 57/06; 13 lipca 2009 r., sygn. akt SK 46/08; 13 stycznia 2015 r., SK 34/12; 24 lutego 2015 r., sygn. akt K 34/12). 
Rozważany termin należy odnieść przede wszystkim do sporów prawnych między osobami fizycznymi i prawnymi, ale ta kategoria nie wyczerpuje całego zakresu konstytucyjnego pojęcia sprawy. W nowszym orzecznictwie Trybunału zanegowano akcentowaną wcześniej zbieżność między sprawowaniem wymiaru sprawiedliwości a rozpoznawaniem spraw w rozumieniu art. 45 ust. 1 (zob. wyrok TK z 13 stycznia 2015 r., sygn. akt SK 34/12). Do zakresu tego pojęcia należą więc wszelkie sprawy, w których dochodzi od „rozstrzygania o prawach danego podmiotu" (wyroki TK z: 10 lipca 2000 r., sygn. akt SK 12/99; 25 lutego 2002 r., sygn. akt SK 29/01; 19 lutego 2003 r., sygn. akt P 11/02; 5 lipca 2005 r., sygn. akt SK 26/04; 22 września 2009 r., sygn. akt SK 3/08; 13 marca 2012 r., sygn. akt P 39/10; 22 stycznia 2013 r., sygn. akt SK 18/11). „Precyzując to założenie TK uznał, że prawem do sądu objęte są wszelkie sytuacje, w których pojawia się konieczność rozstrzygania o prawach podmiotu w relacji do innych równorzędnych podmiotów lub w relacji do władzy publicznej, a jednocześnie natura danych stosunków prawnych wyklucza arbitralność rozstrzygania o sytuacji prawnej podmiotu przez drugą stronę tego stosunku (spory na tle podległości służbowej; wyr. z 10.5.2000 r., K 21/99, OTK 2000, Nr 4, poz. 109)” (K. Weitz, P. Grzegorczyk, Komentarz do art. 45 Konstytucji [w: Konstytucja RP, t. I, Komentarz. Art. 1-86, red. M. Safjan, L. Bosek, Warszawa 2016, nb. 47-55).

W literaturze ugruntowany jest pogląd, że jeżeli ustawy poddają konkretną sytuację pod kognicję sądów, wtedy art. 45 ust. 1 znajduje zastosowanie. „Poddając określone sprawy kompetencji sądów ustawodawca musi się zatem liczyć $\mathrm{z}$ tym, że w sprawach tych aktualizują się gwarancje wynikające z art. 45 ust. 1, bez względu na to, czy kompetencja sądów w tej sprawie jest konstytucyjnie nakazana (tak trafnie TK w wyr. z 7.9.2004 r., P 4/04, OTK-A 2004, Nr 8, poz. 81)" (ibidem). Mając powyższe na względzie, należy uznać, że skoro wydawanie postanowień w przedmiocie wpisów, o których mowa w art. 55 ustawy o KRS, zostało poddane pod kognicję sądu, w sprawach tych aktualizują się gwarancje wynikające $z$ art. 45 ust. 1 Konstytucji.

Fakt, że ustawa nowelizująca pozostawiła kwestię wpisów do rejestru dłużników niewypłacalnych w gestii sądu, świadczy o tym, iż ustawodawca uznaje samoistne znaczenie takiego wpisu, który w sposób wyraźny wkracza w obszar chronionych prawem dóbr osobistych osób prawnych i fizycznych. Z uzasadnienia projektu wynika, że projektodawcy był znany fakt, iż wpisy dokonywane na podstawie poszczególnych punktów art. 55 ustawy o KRS budzą wątpliwości, które wynikają z dotychczasowej praktyki orzeczniczej. Wskazano przykładowo, że wpisy do RDN dokonywane na postawie art. 55 pkt 3 (ujawnienie w rejestrze informacji o zobowiązaniu dłużnika do wyjawienia majątku) dotyczyły osoby, „która nie jest dłużnikiem (np. współmałżonek, który zawarł z dłużnikiem umowę rozdzielności majątkowej) i która nie brała udziału w postępowaniu o wyjawienie majątku, gdyż wierzyciel podał błędny adres jej zamieszkania”. Osoba taka niekiedy dopiero po wpisie do RND „dowiaduje się, że w ogóle toczyło się 
wobec niej postępowanie”. „[Z]darza się również, że ze względu na podanie błędnych danych przez wierzyciela orzeczenia takie zapadają nie wobec dłużników, a wobec osób o tym samym imieniu i nazwisku co dłużnik. W ten sposób osoba, która w ogóle nie jest dłużnikiem i nie ma nic wspólnego z prowadzonym postępowaniem na podstawie postanowienia zobowiązującego do wyjawienia majątku trafia do RDN KRS" (uzasadnienie projektu ustawy nowelizującej, druk sejmowy nr 2067/VIII kad., s. 106). Z kolei, z przeprowadzonych w ramach przygotowywania projektu ustawy badań ankietowych wynikło, że „ujawnienie informacji o zaleganiu z zobowiązaniami alimentacyjnymi przez potencjalnego kontrahenta ma istotny wpływ na wiarygodność osób fizycznych wykonujących działalność gospodarczą" (ibidem, s. 103-104). Trafne są twierdzenia sądu pytającego, że w przypadku dokonywania wpisu do rejestru na podstawie art. 55 pkt 5 ustawy o KRS przesłanką jego dokonania nie jest prawomocne orzeczenie sądu, ale okoliczność faktyczna stwierdzona przez komornika sądowego w trybie art. $1086 \$ 4$ k.p.c., tj. stwierdzenie powstania po stronie dłużnika alimentacyjnego ewentualnej zaległości za okres dłuższy niż 6 miesięcy.

Nie sposób więc uznać, że wpisy do RDN dokonane na podstawie art. 55 pkt 4 i 5 ustawy o KRS mają charakter czysto ewidencyjny i nie tworzą nowego stanu prawnego. Potencjalne podanie do publicznej informacji danych nieprawdziwych lub nieaktualnych dotyczących np. pozbawienia prawa prowadzenia działalności gospodarczej przez określony podmiot albo niewywiązywania się przez niego z obowiązków alimentacyjnych w istotny sposób wkracza w sferę prawnie chronionych dóbr osobistych osób fizycznych i prawnych.

Nieuzasadnione wpisanie danych określonego podmiotu do jawnego i ogólnodostępnego rejestru niewypłacalnych dłużników może godzić w jego prawa. W przypadku osób fizycznych będzie to przede wszystkim prawo do ochrony życia prywatnego, rodzinnego, czci i dobrego imienia. Osoby prawne i jednostki organizacyjne mające zdolność prawną narażone są na utratę renomy.

7. Ocena konstytucyjności art. 49 ustawy nowelizującej w zakresie dotyczącym art. 55 pkt 4 i 5 ustawy o KRS sprowadza się więc przede wszystkim do odpowiedzi na pytanie, czy podmiot, względem którego wydano postanowienie o wpisie do RDN w sprawach wszczynanych w okresie między 15 marca $2018 \mathrm{r}$. a 31 stycznia 2019 r., dysponuje skuteczną możliwością ochrony swoich praw w sytuacji, gdy prawa te zostały, wskutek wydania takiego postanowienia, naruszone lub zagrożone.

Po wejściu w życie ustawy nowelizującej podstawowym środkiem prawnym służącym usuwaniu nieprawidłowości we wpisach ujawnionych w RDN stał się mechanizm przewidziany w art. 12 ust. 3 ustawy o KRS. Przepis ten znajduje zastosowanie w sytuacji, gdy wadliwość wpisu w KRS polega na „niedopuszczalności” wpisu ze względu na obowiązujące przepisy prawa. Sformułowanie „dane niedopuszczalne ze względu na obowiązujące przepisy prawa” jest różnie interpretowane w doktrynie i orzecznictwie. W razie stwierdzenia przez sąd reje- 
strowy, że w KRS są zamieszczone dane niedopuszczalne ze względu na obowiązujące przepisy prawa, ustawodawca upoważnia sąd do wszczęcia szczególnego postępowania $z$ udziałem osób zainteresowanych. Po wysłuchaniu tych osób na posiedzeniu lub po ich wezwaniu do złożenia oświadczenia pisemnego, sąd wykreśla te dane z urzędu. W doktrynie i orzecznictwie przeważa pogląd, że przepis ust. 3 nie daje podstaw sądowi do wykreślenia podmiotu z KRS, a co najwyżej poszczególnych danych o tym podmiocie, jeżeli byłyby one niedopuszczalne ze względu na obowiązujące przepisy prawa. Wykreślenie podmiotu z rejestru, zwłaszcza przedsiębiorcy - głównie ze względu na ochronę interesów jego wierzycieli oraz uczestników - dopuszczalne jest jedynie w okolicznościach ściśle wskazanych w ustawie. Potwierdził to SN w postanowieniu z 27 października, 2010 r., sygn. akt V CSK 114/10. Podobnie wypowiedział się wcześniej SN w postanowieniu z 5 maja 2005 r., sygn. akt IV CK 18/05. Mechanizm przewidziany w art. 12 ust. 3 ustawy o KRS zakłada więc działanie sądu z urzędu, a dodatkowo już po zamieszczeniu danych w rejestrze oraz jedynie w ograniczonym zakresie, w szczególności co do możliwości wykreślenia podmiotu. Przedmiotem dalszej oceny pozostaje więc to, czy art. 49 ustawy nowelizującej zapewnił uczestnikowi postępowania o wpis do RDN właściwą procedurę przed sądem.

Trybunał Konstytucyjny, wskazując na zasadność różnicowania poszczególnych typów postępowań sądowych, podkreśla jednocześnie, że odrębność proceduralna może być potraktowana w pewnych sytuacjach jako ograniczenie prawa do sądu. Swoboda ustawodawcy kształtowania odpowiednich procedur nie oznacza bowiem dopuszczalności wprowadzania rozwiązań arbitralnych, które ponad miarę, a więc bez wystąpienia istotnych racji, ograniczają prawa procesowe strony (zob. wyroki TK z: 20 października 2010 r., sygn. akt P 37/09; 16 listopada 2011 r., sygn. akt SK 45/09).

Istotną gwarancją rzetelności postępowania sądowego jest możność bycia wysłuchanym (prawo do wysłuchania). „Prawo do wysłuchania ma głębokie uzasadnienie w założeniu o podmiotowym, a nie przedmiotowym traktowaniu wszystkich osób zainteresowanych wynikiem postępowania. Jest ono także wyrazem poszanowania godności człowieka" (K. Weitz, P. Grzegorczyk, Komentarz, op. cit., nb 95). Jednym z przejawów prawa do wysłuchania jest tzw. jawność wewnętrzna postępowania sądowego, która oznacza prawo stron i innych jego uczestników do bycia informowanym o jego przebiegu, prawo do wglądu do akt sprawy lub prawo do uczestniczenia w czynnościach procesowych sądu. Jawność ta stanowi przesłankę efektywnego korzystania z prawa do wysłuchania w zakresie, który polega na przedstawianiu swojego stanowiska w sprawie (zob. wyroki TK z: 11 czerwca 2002 r., sygn. akt SK 5/02; 6 grudnia 2004 r., SK 29/04; 20 października 2010 r., sygn. akt P 37/09). Zapewnienie jawności wewnętrznej może następować $\mathrm{w}$ różny sposób. Jednym $\mathrm{z}$ nich jest uczestniczenie stron w posiedzeniach sądowych (niejawnych i jawnych, w tym wyznaczonych na rozprawę), innym - informowanie stron przez doręczenia (zob. wyroki TK z: 17 września 
2002 r., sygn. akt SK 35/01; 28 lutego 2006 r., sygn. akt P 13/05 (K. Weitz, P. Grzegorczyk, Komentarz, op. cit., nb 97). Z orzecznictwa TK wynika również, że możliwość poddania orzeczenia kontroli wzmacnia prawo do sądu, a brak możliwości zaskarżenia orzeczenia je ogranicza (zob. wyroki TK z: 21 czerwca 2005 r., sygn. akt P 25/02; 6 października 2004 r., SK 23/02).

W ocenie Sejmu, penalizujące znaczenie, jakie przypisuje się w doktrynie i orzecznictwie wpisom do RDN, powoduje, że konieczne jest poddanie postępowania sądowego w tym zakresie standardom państwa prawnego, w szczególności zapewnienie uczestnikowi postępowania takiej procedury przed sądem, w ramach której mógłby on bezzwłocznie reagować na postanowienia dotyczących wpisu, które obarczone są istotnymi wadami. Statuowany przez art. 49 ustawy nowelizującej brak wymogu doręczenia postanowień dotyczących wpisów, o których mowa w art. 55 pkt 4 i 5 ustawy o KRS, jak również to, że nie podlegają one zaskarżeniu stanowi naruszenie prawa do sprawiedliwej procedury przed sądem. Ograniczenie prawa do sądu w tym zakresie nie znajduje uzasadnienia $\mathrm{w}$ realizacji innych ważnych wartości konstytucyjnych.

8. Mając powyższe na uwadze, należy uznać, że zakwestionowany przepis w zakresie, w jakim znajduje zastosowanie do wpisów, o których mowa w art. 55 pkt 4 i 5 ustawy o KRS, jest niezgodny z art. 45 ust. 1 Konstytucji.

\section{Bibliografia}

Kowal N. [w:] L. Ciulkin, A. Jakubecki, N. Kowal, Krajowy Rejestr Sądowy i postępowanie rejestrowe. Praktyczny komentarz, Warszawa 2002.

Palmirski T., Wpis do Rejestru Dłużników Niewypłacalnych na zasadzie art. 55 ustawy o Krajowym Rejestrze Sądowym. Stan aktualny - uwagi de lege ferenda, „Rejent” 2009, nr 5.

Tarska M., Komentarz do art. 55 ustawy o Krajowym Rejestrze Sądowym [w:] Kodeks spółek handlowych. Pozakodeksowe prawo handlowe. Komentarz, t. 5, red. S. Sołtysiński, A. Szajkowski, A. Szumański, J. Szwaja, 2015, Legalis.

Weitz K., Grzegorczyk P., Komentarz do art. 45 Konstytucji [w:] Konstytucja RP, t. I, Komentarz. Art. 1-86, red. M. Safjan, L. Bosek, Warszawa 2016. 